\title{
気胸を契機に発見された悪性胸膜中皮腫の一切除例
}

\author{
橋本毅久 1 青木 $\quad$ 正 $^{1} \cdot$ 土田正則 1 ・ \\ 林 純一 1 梅津 㦲 $2 \cdot$ 土屋永寿 3
}

要旨一一気胸で切除した肺から上皮型悪性胸膜中皮腫と診断され, 胸膜肺全摘術, 放射線・化学療法を施行した症例 を経験した．中皮腫の診断には幾つかの免疫染色の組み合わせが有効である．（肺癌．2006;46:169-170）

索引用語——皮型中皮腫, 免疫染色, 気胸

\section{A Case of Malignant Pleural Mesothelioma Detected by Pneumothorax}

\author{
Takehisa Hashimoto ${ }^{1}$; Tadashi Aoki ${ }^{1}$; Masanori Tsuchida'; \\ Jun-ichi Hayashi' ${ }^{1}$,Hajime Umezu²; Eiju Tsuchiya ${ }^{3}$
}

KEY WORDS — Epithelioid mesothelioma, Immunohistochemistry, Pneumothorax

(JJLC. 2006;46:169-170)

症例 : 48 歳, 男性.

職業歴：25歳時にアスベスト吹き付けに 1 年半従事.

喫煙歴：16〜48 歳, 30 本/日.

現病歴：2004 年 11 月右気胸に対して胸腔ドレナージ がおこなわれたが改善せず, 近医にて開胸下にブラ切除 術が施行された．切除標本で悪性胸膜中皮腫，上皮型と 診断され 2005 年 1 月当科に入院した.

入院時現症・検查：身長 $165 \mathrm{~cm}$, 体重 $54.5 \mathrm{~kg}$, 右肺呼 吸音の減弱と気胸手術による開胸創を認める。表在リン パ節は触知しない. CEA $3.0 \mathrm{ng} / \mathrm{ml}$ ，その他の腫瘍マー カーも正常範囲内.

胸部 X 線所見 (図 1)：右胸水の貯留と肺尖部に気胸の 術後性変化を認めた. 明らかな病変部位は指摘できない.

胸部 CT（図 2）：気胸手術後であることや胸水貯留と 末梢の無気肺のため, 肺尖の腫瘤状の部分や胸膜肥厚に みえる部位は腫瘍性病変であるのか不明であった，右横 隔膜に径 $5 \mathrm{~mm}$ の小結節を認めた。リンパ節腫大は認め ない. 気胸手術前, 肺拡張時の胸部 CT では腫瘤性病変は 指摘できなかった。
胸腔穿刺にて血清様胸水 $580 \mathrm{ml}$ を認めたが細胞診は 陰性, 胸水ヒアルロン酸は $21000 \mathrm{ng} / \mathrm{ml}$ と高值であった。 以上ょり悪性胸膜中皮腫, 上皮型, 臨床病期 (IMIG) T1bN0M0 stagelb と診断した。

手術：肺尖部には肥厚した胸膜を認め, 他にも散在性 に小結節を認めた，気胸手術の開胸創部位と心膜，横隔 膜を合併切除し, 心膜・横隔膜を PTFE シートで再建し て右胸膜肺全摘術を抢こなった。

肉眼所見：最大の腫瘍は肺尖部にあり, 胸膜を主体に 一部肺内にも浸潤し, 壁側剝離面では腫瘍細胞の露出を 認めた（図 3-a）。その他腫瘍は胸膜に散在性に存在した (図 3-b). 横隔膜の腫瘍は筋層への僅かな浸潤を認めた。 リンパ節転移は認めなかった。

病理組織所見（図 4)：腫瘍細胞は中〜小型で, 核小体 の目立つ円〜卵円形の核と, エオジン好性で豊かな胞体 を有する異型性の強い類円形細胞が主体で，これらの細 胞がびまん性に増殖し，一部では胞巣も形成していた。 中皮腫に特異的な Calretinin 染色 (図 5-a) は一部で, WT1 はびまん性に陽性, 上皮系マーカーは AE $1 / \mathrm{AE} 3, \mathrm{CAM}$
新潟大学医歯学総合病院 1第二外科, 2 病理部 ; 3 神奈川県立がん センター臨床研究所（病理アドバイザー）.

別刷請求先: 橋本毅久, 新潟大学医歯学総合病院第二外科, T951-8122 新潟市旭町通 1 番町 754.

※第 144 回日本肺癌学会関東支部会推薦症例（平成 17 年 12 月 17
日 日本肺癌学会関東部会).

${ }^{1}$ Second Department of Surgery, ${ }^{2}$ Department of Pathology, Niigata University Medical and Dental Hospital; ${ }^{3}$ Research Institute, Kanagawa Cancer Center (Adviser of Pathological Findings)

(C) 2006 The Japan Lung Cancer Society 


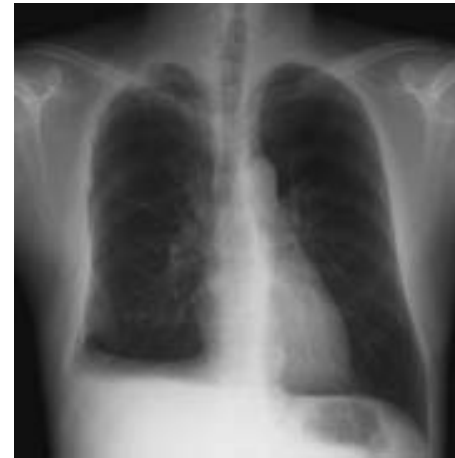

図 1. 入院時胸部レントゲン.

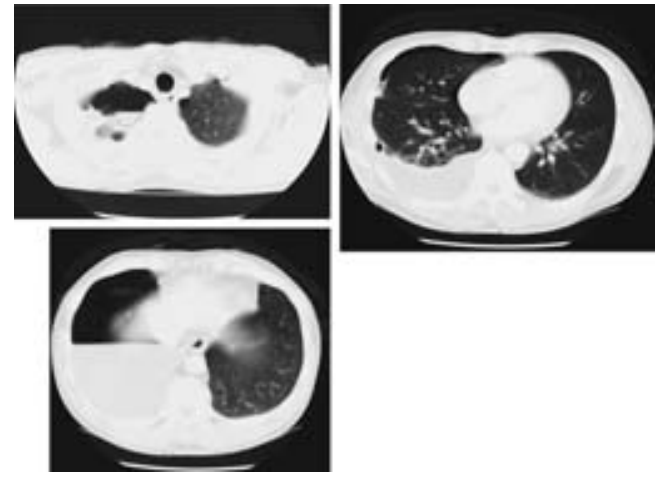

図 2. 胸部 CT. a

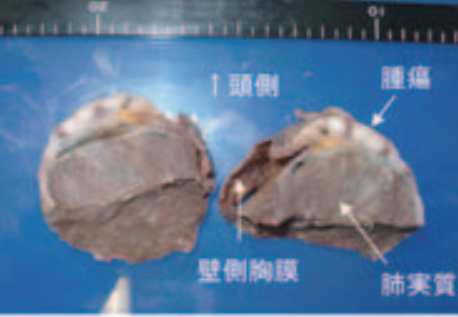

b

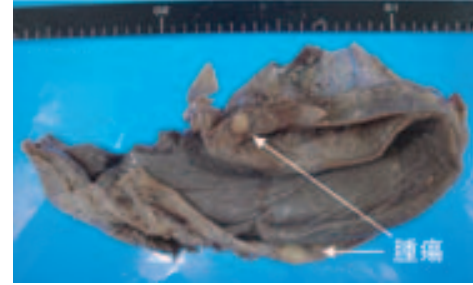

図 3.（a）肺尖部の腫瘍（b）壁側 胸膜の散在性に存在する腫瘍.

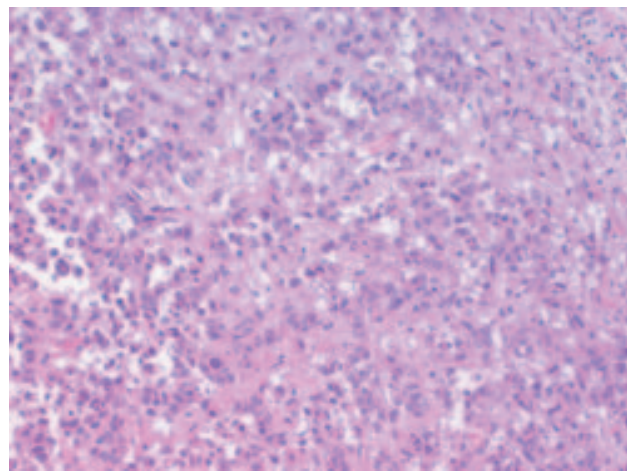

図 4. HE 染色.

5.2, EMA が陽性であった. その他 Vimentin, CD34 が陽 性（図 5-b）であったが, 組織所見と免度染色の結果から 悪性胸膜中皮腫，上皮型と診断した。

術後に右肺尖に $30 \mathrm{~Gy}$ ，右全胸壁に $30 \mathrm{~Gy}$ の放射線療 法と CDDP + gemcitabine の化学療法を 4 コース施行

し, 術後 13 ヶ月現在再発は認めていない.

考察：胸膜中皮腫は胸水貯留に伴う症状によって発見 されることが多く，気胸が初発症状となることは少な い. ${ }^{1}$ 胸膜中皮腫に伴う気胸の特徵としてはブラを伴わ ないことや再発を繰り返すこと，胸水貯留を伴うことな どで，腫瘍の壊死，末梢気管支の閉塞に伴うチェックバ ルブ機構によるブレブ・ブラの発生などが原因として考 えられている。本症例はブラと中皮腫の間には関連が無 いことから偶然にブラと中皮腫が合併したと思われた. 中高齢者の気胸の場合は術前の職業歴の聴取, 術中の胸 膜面の注意深い観察, 切除標本の病理学的確認が必要で ある. 場合によっては胸水ヒアルロン酸の測定も考慮す べきである.

本症例は HE 染色では中皮腫の形態であったが，当初 calretinin はほとんど染まらず, CD34 が陽性になったこ とから鑑別診断として血管肉腫や solitary fibrous tumor などが考えられた. calretinin は染まりにくいことがある

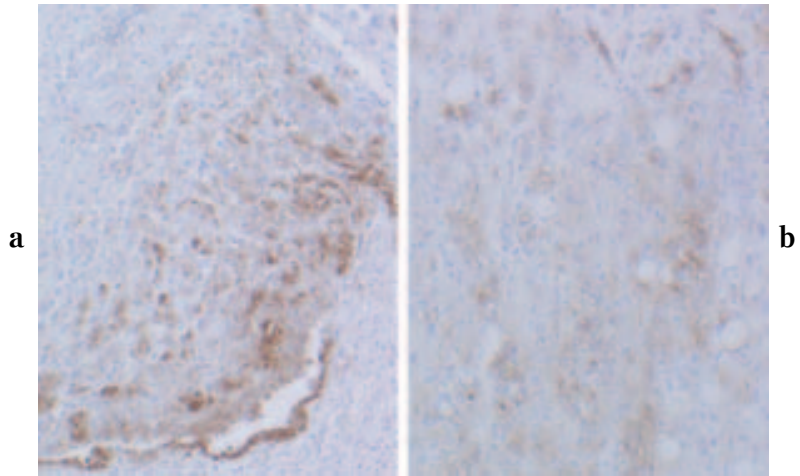

図 5.（a） Calretinin 染色（b） CD34 染色

ことや calretinin だけでは不十分との意見もあり，calretinin の再染色と WT-1 染色を追加した. 最終的に calretinin は一部で陽性, WT-1 はびまん性に陽性となり, 形 態と合わせて中皮腫と診断した. 中皮腫の診断にはいく つかの免疫染色の組み合わせが重要と言われており, 特 に calretinin, WT-1, cytokeratin5/6 それぞれの陽性率は $93 \%$ 以上と報告されている. ${ }^{2}$ 本症例で問題となったの は血管内皮系マーカーである CD34 が陽性であったこと である. 形態と免疫染色の結果から上皮型中皮腫と診断 したが，上皮型中皮腫で CD34 陽性となった症例の報告 はなく，今後の症例の解析が必要と思われた.

\section{REFERENCES}

1. Chung A, et al. Mesothelioma. In: Travis WD, et al. eds. WHO Classification of tumours. Pathology and Genetics of Tumours of the Lung, Pleura, Thymus and Heart. Lyon: IARC Press; 2004:126-136.

2. Ordonez NG. The immunohistochemical diagnosis of mesothelioma: a comparative study of epithelioid mesothelioma and lung adenocarcinoma. Am J Surg Pathol. 2003:27:1031-1051 